

\section{General teology}

The Blashke Islands are underlain by deformed sediments, intruded by an ultrabasic body of roughly circular outcrop.

\section{Bedded rocks}

The sediments consist largely of graywacke and pyroclastic material, with some interbedded conglomerate, black slate, and limestone. The rocks are part of a belt of Silurian $2 /$ rocks that are present throughout much of norther Prince of Wales Island.

The sediments in general dip from 45 degrees to vertical and appear to change in trend around the ultrabasic intrusive and to conform generally with the outline of the intrusive. The sediments in a zone of varying width around the intrusive have been recrystallized to a dense, fine-grained hornfels.

\section{Intrustive rocks}

The southeastern portion of the Blashake Islands is underlain by a roughly circular body of ultrabasic rocks about $1 \frac{1}{2}$ miles in diameter (see fig, 2). Buddington $3 /$ states:
"A cursory examination seems to indicate that the essential features are a core of dumite about a mile in diameter with an encircling. ring of pyroxenite and an outer border of hornblende gabbro-diorite. The two rings of pyroxenit te and hornblende gabbro-diorite are together roughly about three-eighths of a mile wide, though accompanied by outiying masses of diorite in the adjacent sediments."

The core of the ultrabasic intrusive is an oval dumite mass about 6,000 feet by 8,000 feet in outcrop dimensions. Incircling the dunite core is a 500foot to 2,000-foot ring of pyroxenite and wehrlite. The wehrlite tends to be concentrated in irregular patches within the pyroxens te ring near the contact between the pyroxenite and the dunite.

Surrounding the pyroxenite-welarizte ing is an irregular ring of varying width of gabbro with local variants of hornblendite, diorite, argitite and anorthosite. The gabbro phese is gradational with the surrounding sediments.

The contacts between the different ultrabasic rock types generally are intrusive contacts, although many of the contacts between wehrlite and pyroxenite

2/ Buddington, A. $F_{*}$, op, cit, , p, 191.

3/ Buddington, A. F., op. cit., pp. 190-191, 1929. 
are gradational. The core of dunt to solidiffed prior to the bordering ring of pyroxenitie as is proven by the fact that alkes of pyroxenste cut the diunite. The pyroxenite, in turn, is cut by topophyses of the outer ring of gabrow

In gener, the contacts between the various tunits of the ultrabasic body are aproximatiely vertical. Thut the danite core nity be Jikered to a soll d cylinder surrounded by concentric cylindirs of proxenite-wehni te and gebloroic rock: Questionable data from a few magnetometer observations ouggest that the contacts may dip steeply inward."

The following rodk descriptions are based on field ldentiffication and on microscopic exemination of rock powders.

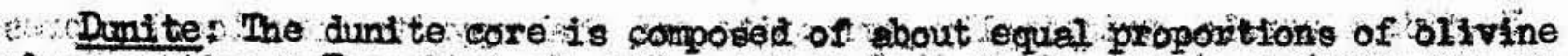
and serpentine. The olivine, witk mean index of refraction of $1.667,18$ clloge\%. to for rterite in composition and contains bout 93 percent of the $\mathrm{Kg}_{2} \mathrm{siO}_{4}$ molectule and about 7 percent of the $\mathrm{Na}_{2} \mathrm{SHO}_{4}$ molecilet.

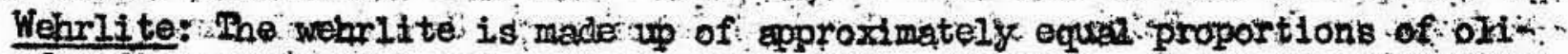
vine of medium grain ei ze and coarsely-crystalline diopside. Index of reforotion: measurements indicate that the olivine in the wehrlite is much richer in iron. $\left(\mathrm{Fe}_{2} \mathrm{SiO}_{4}\right.$ ? 27 percent, $\mathrm{Mg}_{2} \mathrm{Si}_{4}, 63$ percent than is the olivine of the duni te core. 3 The diopside has a teen index of refraction of 1.680 and corresponds to a member... of the diopside-hedenbergite series with 88 percent of diopside molecule.

$\left(\mathrm{CaNgSi}_{2} \mathrm{O}_{6}\right.$ and 12 percent of hedenbergit te molecule $\left(\mathrm{CaFeSi}_{2} \mathrm{O}_{6}\right)$.

Pyroxenite: The pyroxenite is composed principaliy of medium-grained diopside

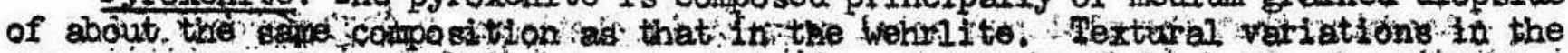

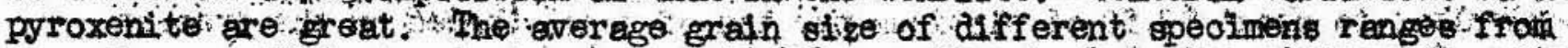
less than a millimeter to several centimetiers. The coarselyo cryatilline diopidde is in irregular segregations of pegmatitic texture, and in more or lpss well : defined pyroxine-enor thil te pegnatite olko, Felespar, mok of which is as ealolic as

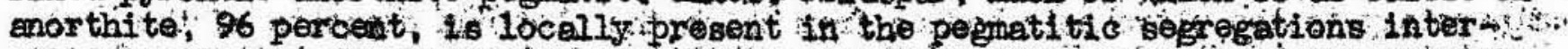
stitial with the diopside, and haj compilso as mich as 50 percent of the peighatite olkes:

Gebbro: The fabbio of the outiex ring is made up largely of feldspar, pyroxene, and their al teration products. the fel olpear. is extremely calcic, typically bytownite or anorthite, ranging in composition from An 80 to An 93. The pyroxene

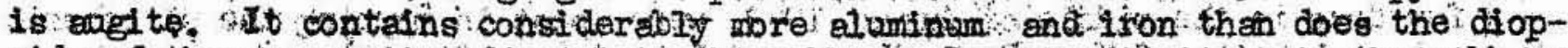
side of the pyroxeni te adjacent to the gabbro. Tocallys diori te teuts the gablo and is probably a late differentiate of the gaboro, The feldspar of this toek ranges from andesine to labradorite.

The relations within each solid-solution series of minengls inal cates that each ring outward was formed at somewtat Iower temperatures then that of the preceding inward ring. The dini te core contains the magnesium-riots ollitine waich: presumably formed at higher temperatures than that of the more iron-rich olivine. of the wehrlite. The calcium-magnesium pyroxene of the pyraxenite presumplily .... formed at higher temperatures than did the more aluminous emd moite ifon-rich 
pyraxene of the gabbro zone. Iilcewi se, the foldopar assaciated with the thore

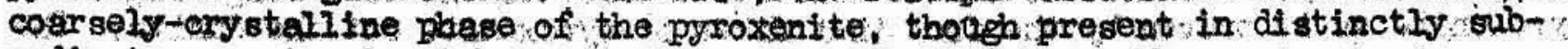
ordinate amounts, is nioher in calcium than that of the gabloro:

Sumeng the chenical relatione whthin this complex: Irom tio centen of the in trusive outwerd, the propontion of megnesi uno decreases abruptiy and the propontione of ealolum, inon, -sill cacend eluminuat increase regularly.

\section{Mineral deposits}

No ohrome spinel was identified in the danite. Nho dunite ji remarkably free of ang spinel group minerals.

Srafide mineral. pxincipally gyrrhotite end congrite, are locally present in the marginal phases of the pyxoxent te and of the gabbro. At pa place werce

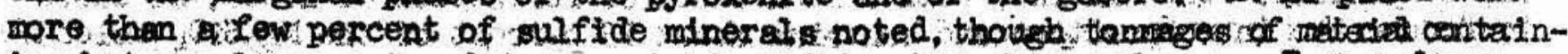
ing between 1 percent and 2 percent of sulfife mineralis ore lange, 2 wo analyres: of the typical sulfide-bearing marginal gabbro were made for nickel, copper and platinum by Cymis feldman of the Chemical Iaboratory, Ceologtcal simrey, Ho reporta:

Specimen

43 A Ke 295

$43 \mathrm{~A} \mathrm{Ke} 306$

\section{5}

Aseuming that the platinum metal preaent is platinum, 0,0003 percent 18 equivalent to bout $\$ 3,50$ of platinum per ton of rock toased on the present price of apgroximately $\$ 35,00$ per oupce of platinum).

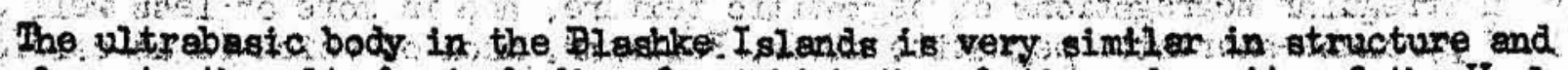
mineraiogy to the ultrabasic bodi es frop which the platinum doposits of the Ural Mounteins were derived, Fowerer, tho possibili ty of placer accumulations of platinum in the Blashice I slands is believed sIight, because of recent glaciation and becaise suitable places of accumlalation of placer materials are lacking.

$\begin{array}{ccc}\text { Cus } & \text { Percent Pt. Metals } \\ 0.0086 & 0.03 & 0.0003 \\ 0.016 & 0.05 & 0.0003\end{array}$

TKATH HIAK, KUPREANOT ISTAND

A fow das in the middle of Aubust 1943 , were spent in mepping the ultrabasic rocks in the vicinity of Kane Roak, Kuypreanof Island (see fig. I) These rocks were bxiefly exemined by Buddington 5$]$ in 1923.

The ultrabasic rocks crop out over an area about $1 \frac{1}{4}$ miles in diameter and extend from near the sumit of Kane Pealk to Jrederick Sound in the vicinity of Cape Straight. (see fig. 3). This region, is, for the most part, covered wi th maskeg, brush and timber, and outerops are sper se except olong the beach and on Kane Peak.

$$
\text { 5) Buddington, A, } 7, \text { Op, cit, } D, 192 .
$$


The ul trobasic intrusiver is in ontact of th thin-bedded Cretaceou gravwacke,

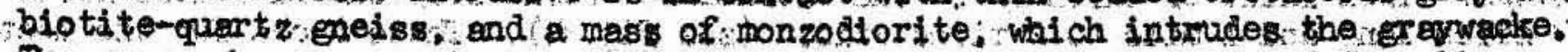
The erewwakse crops out around the nor thern and southern mergins of the ultrabasi 4 body. It strikes, in general, northwesterly and dips about $60^{\circ} \mathrm{NBS}$. How ever, near the contact of the ultrabasic mass with the surrounding sediments, the dip and strike of the foliation and bedding of the sediments is qproximately parallel to the contact of the intmasive, pips are, for the most part, inward. toward the ultrabasic intrugive. Neat the monzodiort te intrusive the graywacke has been senverted to bioti te quart 2 rechi st:

The in trabasic roaks range in comesition from faboro to dunite Wehrilte, pyraxenit te, hornblendf te, and mi carribh zariants of these rocks are locally abundent. Because of the short time arailable for wark in the Kine Feak area, and beceuse of inadequate exposures, the exact relations between these varfous rock, types are not tonown.

In genergit the northern and soptherm moritins of the intrasive mpeat to be

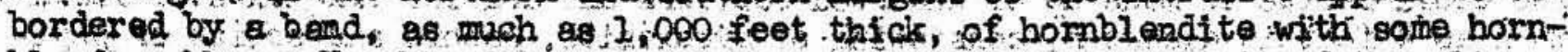
blende gabbro. Hornblendite was not found neer tho wostern limit of the ultrabast, body, for here a portion of tho original al trabasic intrisive is believed

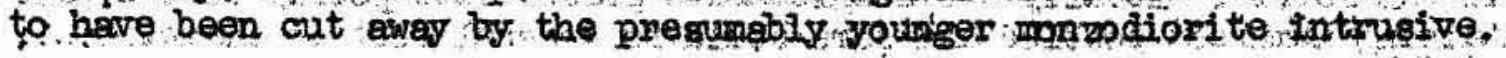

The central part of the body is made us of duntte, wehrifte and diopside. pyroxemite. These rocks locally are extremoly fresh, as on.Kane Peak, but at some places are so highly serpentini ged that the origlnal charecter of the rock has been completely destroyed. . Iocelly parts of these. rocks have been altered to coarse phlogopi te mica.

The ultrabasic rocks that crop out on Kane Feak proper are largely pgroxenite, dunite and wehrlite. The main sboulder of Tahe Reak is pyroxenite contraining about 10 percent to 20 percent of olivine Contacts between the pyroxenite mass and surrounding dunite and wehrlite are gradational, with irregilur areas of dumite in the pyroxenite and some extremely coarse. diopside crystals. In the dunite: Seyeral dike-like masses of dunite cut the pyraxenite, and what appear to be schlieren of pyroxene ere strung out in the dunite.

\section{Mineral deposits}

Wo chrome spinel was noted in the dunite Locally the propxent te contains a few, percent of sulfide ninerals and tho weathered fock is stained a brick-red. Howerer, the sulfide minarals nowhere constittate on appreciable amount of the rock and therefore, the material was not sampled.

$y$ son

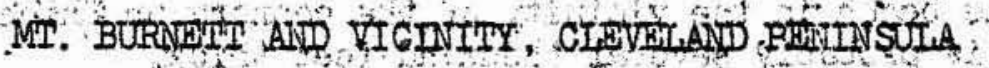

The aithors spent most of September 1943, in a detalled examination of parts of the ultrabasic rocks of Mt. Burnett and vicinity, Cleveland Peninstla.

Mit. Burnett lies on the northwest side of Glevez and Peninsula, about 35 miles northwest of Ketchiken (see fig. 1). The ultrabasic area is accessible from 


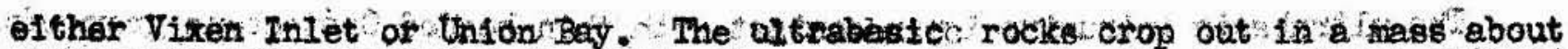

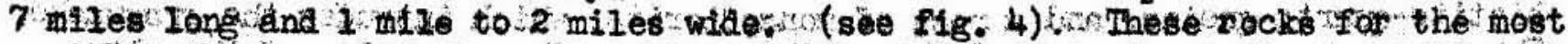

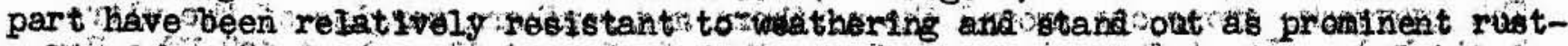
colored bar étidges with antaverage bl ti tade or about 2,000 feet. Soilo develop

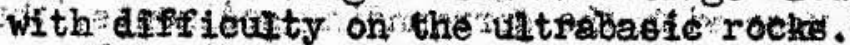

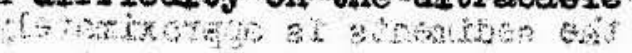

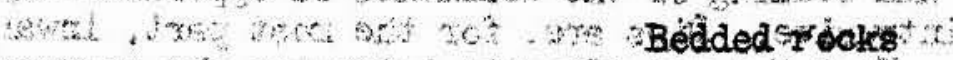

The ultrabasic rocks have intruded phy 13ite and od tat of the Whafigen 1Revillagegedo belt of metamorphic rocks $6 /$. The metamorphic rocks are, for the

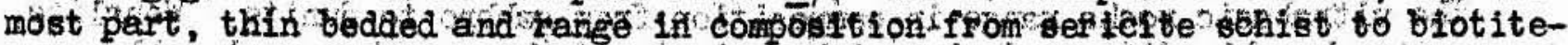

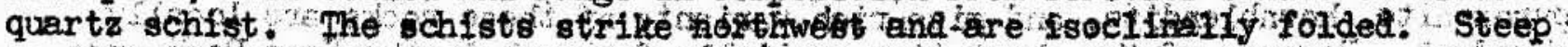
to intermediate dips in both difect of the reeorded:

Tertiary conglomerate, unconformably overlying pyroxeralte" aña phyllite, cröps out for several thousand feet along the beach of Union Bay south of Union Point. The conglomorate is made to of ansarfed boulders and anfular fragments of rock as mach as 4 feet in diameter, cons isting of pyroxentte, gabró and schist or phyl

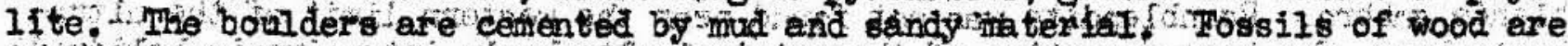
included in the watrix. Jocklly the conglotierate gradé into poorly sorted sand-

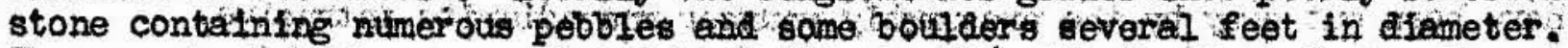
These rocks have been correlated by Buddington 7/ with the Port Camden Bocene rocks.

\section{Titrus fve rocks}

The ultrabasic rocks form a large composite stock, which is mede to of thes diorite, gabbro, hornblendite, pyroxenite, wehrlite and dunite.

The diorite crops out as a booty. the limits of which have not been mapped, Which bounds the uItrablisic nass to the south. Whether this ditorite is a part of the ultrabelic complex or is part of a younger stoek that cut the ult trabasic rocks is not knowsi, at

A crude banding was noted within the ultrabasic mass. The central part of the body is made up largely of dunite, wehrlite and pyroxenite. In general the eastern portion of the body appedrs to be largely dunite, whereas the western part is largely pyroxenite. These distinctions are not sharp because the dunite contains many irregular patches of pyroxentite and wehrifte and the pysoxenite contains many areats largely of dunite. The central mast of pyoxentte and dunte is separated from the surrounding schlsts by bordeting factes of pyroxenite, hornblendite and gabbro. The marginal hornblendite and gabbro is particularly well exposed along the beach in the vicinity of the cannery on Union Bay, where the hornblende zone is probably several thousand feet thick.

6/ Buddington, A, F, op. cit,, pl, 1 .

7) Buddington, A, F, op. cit, p. 263. 
- is at every place where contact relations were observed pyroxenite of the

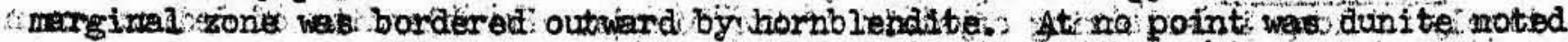

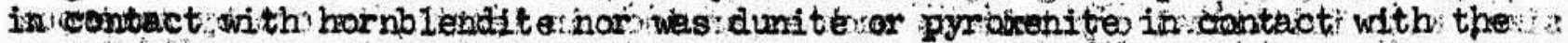

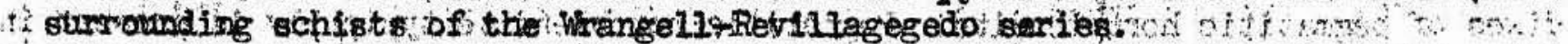

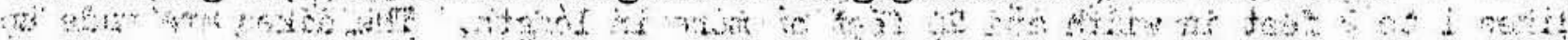

Dunite: The dunite vais examined in considerabler deteili in thes estern portion

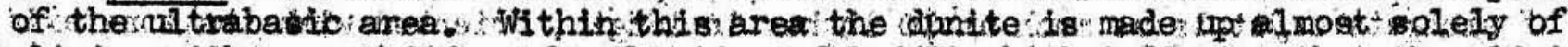
olivine with a mean Index of refraction of $11667 \%$ whish indicates that the olivine

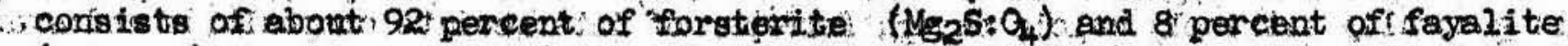

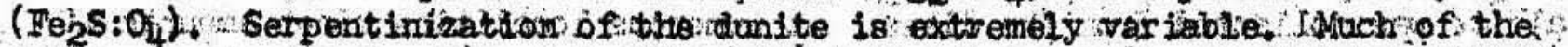

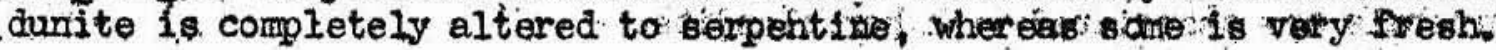

The dunite, It ist belleved, was deformed after it obnsoltoted, Parallel

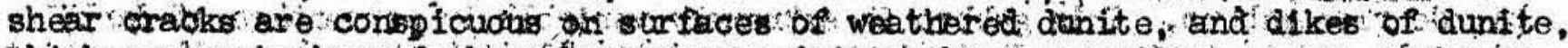
which are woh sheared, have ber bqueezed into the pyrostensto.

Pyroxenite: Two varieties of proxenite are present: A variety of pyroxenite which lies near the outer limits of the ultrabasic body, between the dunite and

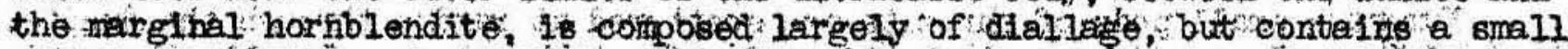

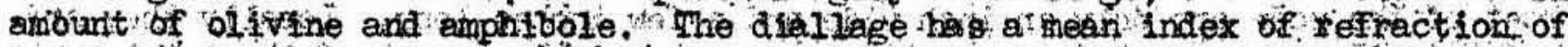

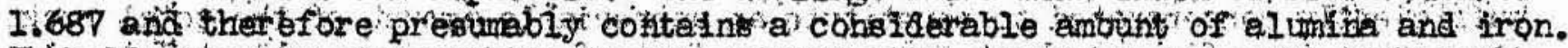
The ollvine present in minor quant it ies ith the pyrotenite is considerably richer in Iron than that of the tentrel zone. It's tiean Indef of refraction is 1.688 which

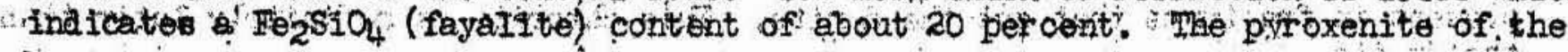
border zone is typically extremely variable in grain size; locally veins and irregular segregations of pyroxene, of pegmatitic texture, with crystals several Inches in length are surrounded by pyroxente of finer grain size.

Considerable magnetite, probably titaniferous, is associated with the pyroxenite of the border zone. Nost of the menetfte is intersitital to the pyroxentte and appear to have been one of the last components of the rock to orystalize. Some velitilike magnetite masses, 1 inch or more in width cut the pyroxentte. The marginal pyroxenite' is also cut by dikes of the nearby Hornblendite and hornblende gabbro.

A second type of pyroxerite occurs In irregular messes within the central dunite, and numerous dikes of this pyesxente cut the dunite. This pyroxenite is made up almost exclusively of diopside with an index refraction of about 1.678 , indicating that it contains about 92 percent of diopside ( $\mathrm{CaNgSi}_{2} \mathrm{O}_{6}$ ). molecule and 8 percent of hedenbergite $\left(\mathrm{CaFSI}_{2} \mathrm{O}_{6}\right)$ molecule.

Wehrlite: Irregular areas of wehrlite, gradational with dunite and with. pyroxenite, are present within the dunite and pyroxenite masses of the central zone. The wehrlite is made up of diopside crystals, which are as much, as 2 inches across, in an olivine matrix. In general, however, the intermediate rock type, wehrlite, is much less common than either pyroxenite or dunite. For the most part the rocic minerals seem io have aggregated into rocks of essentially mono-mineralic composition. 
Hornblenditer. The hornblendite is a massive dark rock composed almost ontirely of long intionlocking cryitals of hornblendes Hornblendite of meds un grein

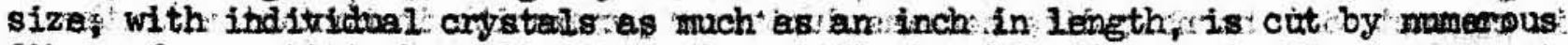
dikes of pegmatitic hornblendite. Pegnatitie hornblendite typically is present in dikes 1 to 2 feet in width and 20 feet or more in length. The dikes are made up of hornblende and subordinate anounts of feldspar. The hormblende is in the form of elongate cry tals as mach as 10 inches in length oriented with the long axis of the crystil at right angles to the walls of ther dike; Ieldspar, dithere present, is generally extremely calcie though feldspar of Internediato counosition and even albite was collocted from the dikes: at numerons locelitiles minor mounts: of : sulfide minerals are associated with hornblendite.:

Gabbro: Oatward, towerd the schia ts, the hornblendi te grades into a horn-". blende rich gabro. This gabbrb is extremely variable in percontage of daris minerals and in texture. It is in turh, gradational with tho surrounding schists.

\section{Mineral deposits}

Numerous small pods of chromite are scattered at vandom through the dunite. Most of the pods are onlve an inch wide and a few inches $30 \mathrm{ng}$. Iocally they are sufficiently concentrated to onstitute an appreciable amount of the totad rock. At point A (aee fig, 4) about 5,000 square feet of outerop are astimated to contain about 5 percent of irregular ohromite segregations. Narch of the chromite is present in fractures that eut the dunite This chromite is definitely later than the dunite.

At point $B$ (see fig, 4) a single body of massive chromite was found that is estimated to conta in about 25 tons of chromite. The body in outcrop dimensions is about 13 feet long by $1 \frac{1}{2}$ feet wide. The body is massive, black, slightly magnetic chromite, surrounded by dunite. Movement along minor fractures has of fbet part of the body a few inches. Analyses of specimens of chromite from these two jocalities have been made by John E. Husted, of the Chemical laboratory of the Geolugical Survey. The analyses are given below:

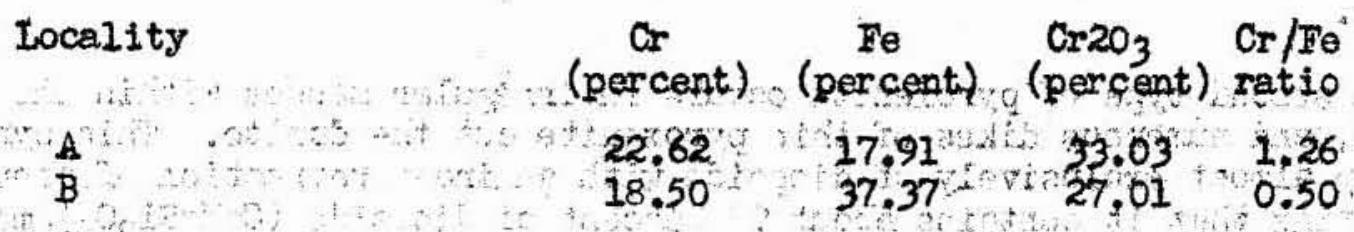

Because of the low grade and the poor chrome-iron ratio this chromite is essentially of no value.

May, 1944. 


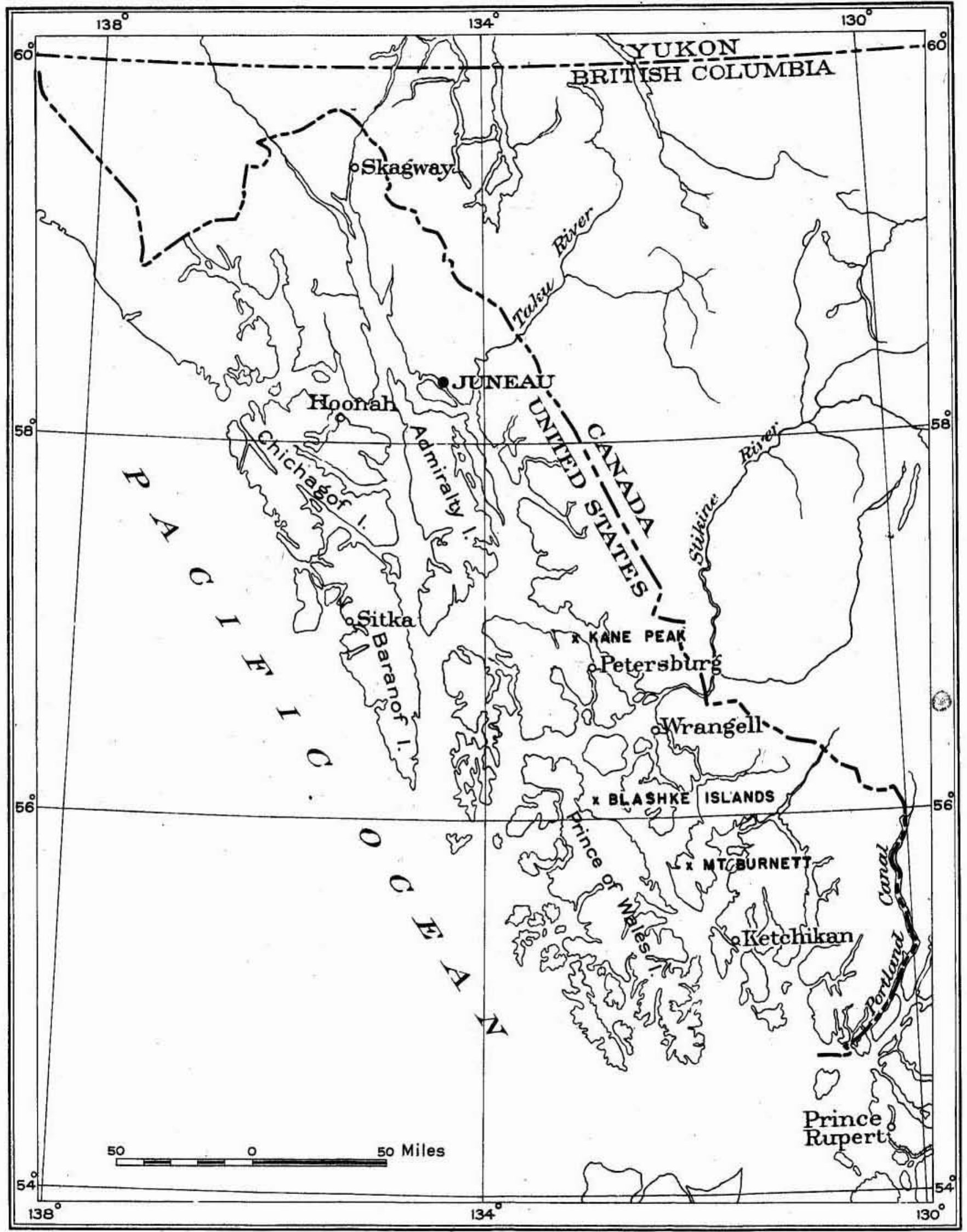

FIGURE I.- INDEX MAP SHOWING LOCATION OF BLASHKE ISLANDS, KANE PEAK AND MT. BURNETT DIFFERENTIATED ULTRABASIC BODIES, SOUTHEASTERN ALASKA 


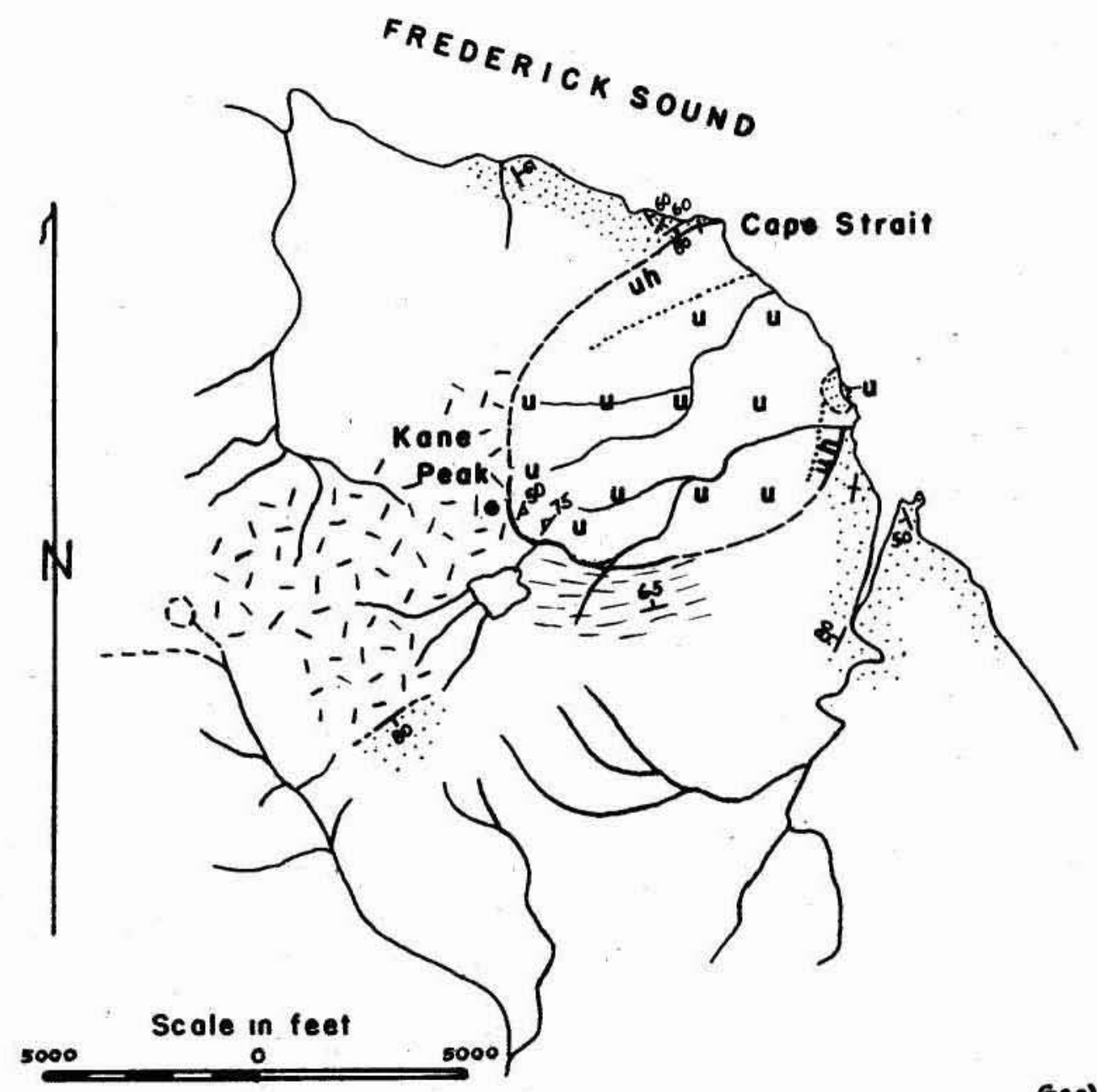

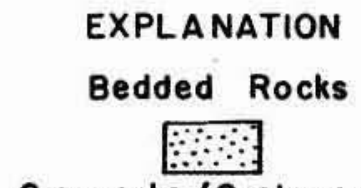

Graywacke (Cretaceous)

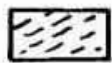

Biotite-quartz gneiss

Intrusive Rocks

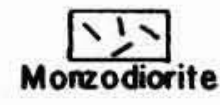

uh

Hornblendite

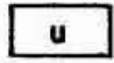

Ultrabasic rocks, largely dun-

ite wehrlite, and pyroxenite

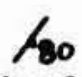

Strike and dip of bedding or foliation

Gealogy by M.S.Walton and G.C. Kennedy

FIGURE 3. - GENERALIZED GEOLOGIC MAP OF KANE PEAK AND VICINITY, KUPREANOF ISLAND. SOUTHEASTERN ALASKA

41761 